\title{
Emergency Response and Communication During Bili-Bili Dam Flood Crisis in Indonesia
}

\author{
RAHMITA SALEH \\ YUSMANIZAR \\ Universitas Fajar, Indonesia
}

\begin{abstract}
The high rainfall intensity in the South Sulawesi region in January 2019 has increased the water level of the Bili-Bili Dam. It has raised alert status and enforced the Dam manager to carry out emergency responses and open the spillway to anticipate water overflow which has ultimately caused floods in the Gowa Regency area. This study aims to describe and analyze the emergency responses and communications carried out by Balai Besar Wilayah Sungai Pompengan Jeneberang (BBWSPJ), as the manager of the Bili-Bili Dam, in dealing with the crisis. The research has applied case study approach, using in-depth interviews and document analysis. The study finds that the emergency responses are carried out based on the Emergency Action Plan and Standard Operational Procedures documents. The responses should involve some related government bodies. There are four levels of hazard status, namely normal, wary, alert, and caution. The higher status would involve the higher government bureaucracy. The study also finds that local people are posited merely as audience or object of the emergency responses. This study proposes that crisis awareness needs to be shared to all stakeholders through developing and implementing appropriate crisis communication planning. Involving locals and stakeholders will provide public understanding about what kind of crisis is happening and what are the right actions should be taken. The role of public relations should be highlighted to increase public trust in the organization's ability to manage the crisis.
\end{abstract}

Keywords: Emergency response, emergency communication, flood crisis, crisis communication planning, crisis awareness.

\section{INTRODUCTION}

The high rainfall in South Sulawesi Province since January 20, 2019 has resulted in floods, landslides and whirlwind in 13 regencies (Taufiqqurahman, 2019). It was a large-scale disaster in South Sulawesi Province because previously the floods in the rainy seasons only occured in the district scale. It has also caused the Bili-Bili Dam located on the Jeneberang River in Gowa Regency raised Alert status for the first time. Water Level (Tinggi Muka Air/TMA) which reached an elevation of +101.87 meters on January 22, 2019 was the highest since it was operated in 1999 (Biro Komunikasi Publik Kementerian Pekerjaan Umum dan Perumahan Rakyat, 2019). The rainfall intensity and the water discharge from the Jeneberang River coming out from the dam, as well as the water flow from the Jenelata River (Tribun Timur, 2019) has resulted in flooding in the riverbank areas with the height up to $200 \mathrm{~cm}$ (Nugroho, 2019). It has made Gowa District being one of the most severely affected area by the floods, where there were 2,120 people displaced, 500 houses were inundated and various public facilities were damaged.

This shows that both the government and the community, have not had preparation in dealing with disaster. Anticipation of the disaster has been carried out by the dam manager five months before the incident by conducting work meetings and outreach to the government at the district level, the police, and the Regional Disaster Management Agency 
(Badan Penanggulangan Bencana Daerah/BPBD), but appropriate actions to anticipate the weather conditions that can cause disasters, as informed by the Meteorology, Climatology and Geophysics Agency (Badan Meteorologi, Klimatologi dan Geofisika/BMKG), were not prepared later. The lack of public understanding of the situation has also encouraged the community to be unprepared to evacuate and make rescue efforts independently.

This research examines the crisis communication prepared by the dam managers in explaining the crisis situation and actions taken at that time. The object of the research was crisis communication activities conducted by the managers of the Pompengan Jeneberang River Regional Center (Balai Besar Wilayah Sungai Pompengan Jeneberang/BBWSPJ) of the Bili-Bili Dam in handling emergency situations due to extreme weather in January 2019. The unpreparedness of the community to deal with emergency situations of the dam was also caused by the unpreparedness of the government and dam managers in anticipating and communicating risks. In this sense, this study expects to encourage serious attention from the public authorities to the crisis and risk communication in order to increase the community preparedness in dealing with risks and disasters.

\section{LITERATURE REVIEW}

In this section, previous studies which are relevant to this study are reviewed. First, communication gaps in handling disasters between actors. Second, the aspect of crisis communication in disaster management. Third, changes in the disaster management approach in Indonesia from disaster emergency response to disaster risk reduction. Fourth, the theoretical basis for crisis communication known as the crisis and emergency risk communication model (CERC), an integrated model of communication planning before and after the crisis.

\section{Crisis Communication}

From the point of view of public relations, crisis communication deals with the strategies in managing and framing public perceptions of an event (Paltalla et al., 2012). Crisis communication is one of the functions of public relations that requires skill of communicators to handle and explain the position of the organization in dealing with crisis threat and uncertainty situations (Reynolds \& Seeger, 2005). Planning a good communication crisis makes the organization is able to explain to the public what is happening, identify consequences, and provide the information needed accurately and in accordance with the needs of the affected communities.

In carrying out its role, PR officer manages all forms of information needed and determines who must receive the information in order to achieve organizational goals. The process of organizing information could be analysed based on the organizational information theory that has explained the processes by which organizations collect, manage, and use the information they receive (West \& Turner, 2008). The processes involve the connection of units between departments in carrying out information processing tasks, and the hardest part is in interpreting and distributing information.

In the context of disaster communication, crises are usually characterized by potential levels of dangers (Spence, Lachlan \& Griffin, 2007). Crises are also dynamics, unexpected events that cause threats and uncertainties (Collins et al., 2016). In a situation of uncertainty, the demand for disaster-related information has increased sharply (Nazaruddin, 2017). So that in planning the communication strategy, contextual factors need to be considered. Therefore, communication plays important roles in explaining the crisis to the 
public, so that they can identify and anticipate the possible impacts of the crisis, and what needs to be done to deal with it. The organizations must also be able to respond promptly, accurately and confidently during the emergency in the hours and days that follow. It is due to the information need in the society about what happened and what are the impacts. Therefore, it is necessary to plan crisis communication based on the needs of the society.

Crisis communication has informative function, which aims to prevent negative outcomes resulting from a crisis (Spence, Lachlan \& Griffin, 2007). Messages sent during the crisis period can encourage recipients to take action to avoid risks based on rational understanding. Thus, the messages should be able to explain the direction of the current situations regarding the crisis and what actions should to be taken. During the crisis, the information search will increase. It needs to be considered in planning crisis communications, because everyone has limited capacity to interpret appropriately new information.

Crisis communication should provide enough information to make decisions, and the decision is then communicated to the stakeholders. Common understanding of the crisis among crisis management team and participants, can manage participants' reactions to the crisis. Certain steps should be taken in managing information about disasters, including gathering information, analysing threats, sharing information, collaborating with stakeholders, coordinating early warning, planning and evacuating, and developing and implementing public education (Puspito et al., 2015). Each activity requires communicative, empathetic, and intelligent people, as well as strong leadership.

\section{Communication Gaps in Disaster Management}

The reviews in this section provide some insights on how the coordination and the role of public authorities, non-governmental organizations, and stakeholders in providing information to reduce the risk, especially to the potentially affected communities. Shittu, Parker \& Mock (2018) who have studied Hurricane Katrina and Haiti Earthquake shown that coordination failure contributes to the fail efforts in implementing emergency preparedness and responses after a disaster. They argued that the absence of information flows between organizations involved in disaster management usually results in poor performance and communication. Pyles et al. (2017) found that civic engagement increases community resilience and efficient use of resources. On the other hand, inadequate coordination between governments and stakeholders leads to the lack of preparedness and collective responses (Parker et al., 2009).

The importance of the role and coordination of various parties in disaster management provide an overview of the effectiveness of communication and readiness to handle crisis situations. Paltalla et al. (2012) emphasized that authorities must provide information as quickly as possible without ignoring accuracy and responsibility. But in the communication processes with citizens, authorities usually use intermediaries so that they do not communicate directly to the public. This can lead to accusations to the authorities regarding their inability to provide information. Other gaps can arise in the processes of handling disasters if various actors who are involved, such as public authorities, nongovernment organizations, and stakeholders, have their own ways in dealing with the crisis. Inadequate knowledge of the roles, tasks and models of work between actors can hinder the ability to work together, so it is important to increase cooperative trainings. Public 
authorities should also emphasize their position as the main source of information to deal with the communication gaps.

\section{Disaster Management Approach in Indonesia}

The 2004 Indian Ocean Tsunami was a turning point in risk reduction and management in Indonesia (Djalante et al., 2017). The disaster management approach has transformed from the emergency responses into a more comprehensive and preventive disaster risk reduction. This change was also due to the establishment of a framework and ratification of Law 24/2007 on Disaster Management, as well as the establishment of the National Disaster Management Agency (Badan Nasional Penanggulangan Bencana - BNPB) and the Regional Disaster Management Agency (Badan Penanggulangan Bencana Daerah - BPBD). These agencies have functions to plan and implement disaster risk reduction, to lead the emergency responses, as well as to manage the reconstruction and rehabilitation programs after the disaster.

However, Indonesia still needs to build a culture of safety, preparedness and resilience through increasing knowledge about disasters and risks and training in preparedness for the community, especially for the most vulnerable to hazards (Djalante \& Garschagen, 2017). Another study was conducted by Mardiah, Lovett \& Evanty (2017) and found that the progress of DRR in Indonesia is still focused at the national level, it requires some local level efforts, such as strengthening local institutions, increasing community empowerment and adopting approaches that are integrated with the development. Djalante \& Garschagen (2017) has also shown that the president's leadership role, as well as social and political changes, have contributed significantly to the pattern of disaster management.

The CERC Model

The CERC (Crisis and Emergency Risk Communication) model was developed by Reynolds \& Seeger (2005) as a comprehensive approach that combines risk communication and crisis communication into a broader form of communication. This model can be used as a tool for professional in communication field to adapt the communication activities with the public needs so as to facilitate the public in making better decisions to protect themselves (Aerts, 2013). This model consists of five stages which assume that the crisis will develop in ways that are predominantly can be predicted. The value of a systematic approach is to reduce uncertainty and allow crisis managers to anticipate further communication needs and problems. This model also recognizes that effective communication about crisis must begin long before events occur and continue until the threat subsides.

The CERC work model consists of five stages (Reynolds \& Seeger, 2005), namely:

a. Pre-crisis. It should be started with education and campaign to the public to prepare themselves for the possible hazards and crises.

b. Initial event. The institution should intensively communicate to reduce uncertainty for the affected communities, and conversely to build certainty.

c. Maintenance. It is important to communicate to the general public and the affected communities for a prolonged reduction of risk and uncertainty which should be collaboratively conducted with the public. 
d. Resolution. It consists of creating public understanding of the potential risks in the future, managing recovery, and strengthening a positive corporate image.

e. Evaluation. In this stage, the effectiveness of crisis communication should be evaluated.

In the special cases of extreme weather events, the CERC model could be simplified according to the stages of a disaster event (Aerts, 2013), which is intended to show communication processes and behaviours, including the search for information and selfprotection, during the pre-crisis, crisis, and post-crisis stages. The use of this model will also allow the development of risk communication model in order to reduce the future potential hazards.

\section{METHOD}

This study examines crisis communication in the emergency preparedness and responses carried out by BBWSPJ while handling the increase of the Bili-Bili Dam water level. This study has applied qualitative approach with the type of singular case study (Mohajan, 2018). The data collection involves semi-structured interviews, documents, and archives. The primary data were collected from the interviews with the stakeholders 10 days after the disaster. While the secondary data were collected from the relevant documents, such as standard rules for disaster management used by the BBWSPJ.

Interviews were conducted with the dam manager and the affected communities, applying a combination of purposive and snowball sampling technique. The first stage was carried out by doing the interview with the Head of the Operations and Maintenance Planning Section (OP) BBWSPJ, and the staffs involved in the handling processes during the emergency situation. The interview was conducted to obtain information on the emergency preparedness and responses carried out during the emergency period. It was also expected to know the procedure and its implementation of the communication model related to the crisis, especially when the indications of flood are happening, as well as when a flood actually occurs. The second stage was interviews with two peoples in the Pakkatto area, which is located within 4 kilometres from the dam and two peoples of Pallangga Subdistrict who were affected by floods in the downstream area.

The study has also used certain relevant documents, such as the Emergency Action Plan Report (Kementerian Pekerjaan Umum dan Perumahan Rakyat, 2018), as well as Guidelines of Emergency Action Plan of Bili-Bili Dam (2018), in order to describe comprehensively emergency handling and communication actions. The archives were also obtained from the five years round of RTD consultation meeting that was conducted in 2018 , four months before the crisis situation occurs. The data were inductively analysed and categorized mostly based on the level of hazard status category of the Bili-Bili Dam.

\section{RESULTS AND DISCUSSION}

This section describes the crisis handling procedures of the Bili-Bili Dam management, as well as the implementation of such procedures during the flood crisis in January 2019. The description will give special attention to the communication activities conducted by the dam managers during the crisis. This section also discusses these research findings with the relevant theoretical frameworks, especially crisis communication theories, emphasizing the 
importance of crisis communication management in handling emergency situations.

\section{Emergency Response and Communication During The Crisis}

The study was conducted 10 days after the emergency situation of the Bili-Bili Dam due to the increase of the water level reaching 101,87 meters. This number has set Alert status on January 22, 2019 at 13.40 (SISDA BBWSPJ, 2019) because it was closed to the maximum limit of the water level, which is 103 meters (Rusdianto, 2019).

In the operation pattern of the Bili-Bili Dam (Biro Komunikasi Publik Kementerian Pekerjaan Umum dan Perumahan Rakyat, 2019), there are four levels of hazard status and three conditions of emergency response to hazard status.

Table 1: Bili-Bili Dam hazard status and emergency response

\begin{tabular}{ccc}
\hline Hazard Status & TMA & Emergency Response \\
\hline Normal (Normal) & +99.50 meters & - \\
Wary (Waspada) & +100 meters & $\sqrt{ }$ \\
Alert (Siaga) & +101.60 meters & $\sqrt{ }$ \\
Caution (Awas) & +103 meters & $\sqrt{ }$ \\
\hline
\end{tabular}

The operation to handle the emergency situation of the Bili-Bili Dam began on January 21, 2019 at 14.00 when the TMA reached +99.45 elevation. Based on the Guidelines of Emergency Action Plan (SOP), the reservoir overflow operating doors must be opened gradually because there are indications that the water level continues to increase. According to the Head of the Operational Section, 5 minutes before the opening of the spillway door, an early warning system was operated by giving notifications to the public through loudspeakers, which has a radius of $4 \mathrm{~km}$, to avoid from the river water flow. This warning was delivered in two languages, namely Indonesian and Makassar languages, targeted at people who moved around the watershed within the radius, to stop the activity and avoid the river because there would be a spillway door opening that caused heavy flow of water. This warning system was carried out until the morning of January 22, 2019. Besides, communication was also carried out using telephone lines within the dam management scope to monitor the situation. The Head of the Operational Section explained:

"So, our SOP is like that. When we want to open the spillway, there is an announcement to the downstream communities. There are two warning systems, for opening the spillway and for evacuation. For opening the spillway door we use a loudspeaker whose radius is $4 \mathrm{~km}$, and for the evacuation we use siren whose radius is $10 \mathrm{~km}$. So, we do the first warning system when we open the spillway, and we use two languages, so the announcement is also in Makassar language" (Head of the Operational Section, interview, 4 February 2019).

In my opinion, the steps taken by the manager based on the RTD have been carried out appropriately to deliver emergency messages, so it did not cause panic. Preparedness refers to the situation where there is a potential disaster, whether a disaster will possibly occur or not. So that, during this situation, which is still in a low intensity, the crisis communication must be informative and clearly arranged so it does not cause panic and unexpected aggressive behaviour. By understanding the needs of the target audiences and local vulnerabilities, it is easier to develop disaster preparedness and management 
strategies (Collins et al., 2016).

However, this research found a different matter in the field, that the information received by the community, especially those within $4 \mathrm{~km}$ radius in the Pakkatto region, came from the Village Head through social media, especially Whatsapp. The message delivered was in the form of a notification to wait for information regarding the evacuation efforts to be carried out. In this area of $4 \mathrm{~km}$ around the dam, the height of water inundation was $5 \mathrm{~cm}$. Likewise for the people who are in the downstream in Pallangga Subdistrict, more information was received from social media, information from the government just existed when the dam was in the danger status. An informant from the Pakkatto village has asserted:

"I am not sure whether I heard the announcement from the loudspeaker or not. The only message we received from the authorities was that we must be prepared to be evacuated. That was conveyed by the village head through the WhatsApp" (Local people from the Pakkatto village, interview, 7 March 2019).

When the monitoring status of the elevation reached +99.69 meters and there was an indication that TMA will increasing, according to the Head of the OP Section, the response to the emergency action was started. At first, the Head of BBWSPJ submitted reports and notifications about the dam condition and the implementation of the RTD to officials, especially the Directorate General of Water Resources, Gowa Regency, and another related agencies by using telephone lines.

At $12: 45$, the elevation reached +101.38 meters and was set as Wary status (SISDA BBWSPJ, 2019). In this situation, the Head of BBWSPJ led the implementation of the RTD, acting as a spokesperson and activating the Emergency Operations Command Post as a hazard information centre. Publication and information to media were also carried out through SMS and telephone channels so it has increased the coverage and reports from regional and national news media.

The emergency communication flow in the Wary condition was still within the scope of the dam manager, but when the water level increasingly enhanced then the dam manager should coordinate with the Head of the OP and analysts. In this plot, if the situation can be controlled, the emergency will be terminated. However, if the conditions are deteriorated and the experts assess that there will be potential for disaster, the status will be increased to Alert and will be continued to evacuate the people within the danger zone 1 . In this situation, based on the RTD guidelines that have been socialized among agencies, information should be delivered to the public and evacuation handling become the responsibility of Gowa Regency Government, as Gowa Regency is the most affected area.

When the status of Wary occurred, the Gowa Regency Government began to delivering emergency information to the public through social media, especially Instagram and Facebook, as well as through danger warning patrol cars. The information submitted was asking public to prepare for the disaster and immediately evacuate from the riverbank area. 
Although manager and government have communicated the emergency situation to the public, the steps they have conducted based on the RTD guidelines still need to be evaluated. This is due to the slow process of the emergency information so that public was not prepared for the risks that threaten them. A few hours before government announced to public about the emergency situation, information had reached public through social media, especially Facebook and Instagram. They discussed the disaster in various points, but what actions should be taken with the situation were not described during the emergency situation. As a result, public responses to the risks were different, including their behaviour of information seeking to reduce anxiety. Thus, the government and managers must educate public about information channels that can be used to obtain fast and accurate information about what is happening and what actions should be taken.

Because the situation was still not able to be controlled by the management due to the high rainfall, at 13:40 the dam was determined in the Alert status because the TMA had reached +101.64 meters (SISDA BBWSPJ, 2019). The water volume of the dam was 279,17 million cubic meters, the inflow was 956,425 cubic meters.

In this situation, based on RTD, coordination and monitoring for the dam repair and safeguards should be improved. The communication flow for this situation, based on the SOP, was carried out to the Head of the UPB for the processes of repairing and securing the dam, as well as to Gowa Regency Government for the evacuation processes. If conditions can be controlled, then the emergency is terminated. However, if the danger condition continues, a request is made to the Regional Disaster Management Agency (BPBD) and related agencies to begin partial evacuation of residents living on the riverbanks and who have high level of vulnerability. If the efforts to prevent the collapse of the dam are unsuccessful and the dam conditions are getting more critical, then the emergency situation will be set in a state of Caution.

The handling carried out in the Alert condition to prevent over topping was to fully open the two spillways so that the outflow from the dam was 956,424 cubic meters. This handling was done to save the dam from collapse if it holds more water which can have an impact on wider disasters. But the decision to drain all incoming water has caused the downstream area and the Jeneberang watershed to experiencing severe flooding. Evacuation efforts were finally carried out by BPBD with the district level police (Polres) and military office (Kodim) on the afternoon of January 22, 2019, from the Pallangga Sub-district to the Pangkabinanga Sub-district, because the area had been submerged in $50 \mathrm{~cm}$ of water and continued to rise up to $200 \mathrm{~cm}$.

Alert status continued until the elevation reached +101.87 meters at 18:00 and lasted until 20:00. At 20:10 the TMA started to go down at an elevation of +101.86 meters and continued to fall down until +100.77 meters at 11.00 on January 23,2019 . In this situation, the efforts to prevent dam failure were successful so that the emergency was terminated. But the processes of handling disasters after the emergency situation were still being carried out by the agencies within the Gowa Regency Government. The decision that the emergency situation ended was made by the Head of BBWSPJ as the leader of the RTD implementation, while the final determination of the emergency responses in the downstream dam was carried out by the regent. It was recorded that 3 people died, 45 people were injured, 2,121 people were displaced scattered in 13 evacuation points, and more than 500 housing units were flooded (Nugroho, 2019). 


\section{Further Discussion and Practical Recommendation}

In the disaster management cycle, there are four functional components, namely mitigation, preparedness, response and recovery (Budi, 2012). The four components are currently the platform for handling disasters. Two components are the pre-crisis phase, mitigation and preparedness, and two components are the post-crisis phase, response and recovery (Fischer, Posegga \& Fischbach, 2016). Mitigation includes the reduction or elimination of hazard risk components. Preparedness includes activities to equip people who are at risk of disaster, to be able to help each other in disaster events with various tools/equipment, and to improve their ability to survive and minimize financial and other risks. Response includes actions taken to reduce or eliminate the impact of disasters. Recovery includes repair, reconstruction or reaching back from what has been damaged/lost and ideally reducing the risk of the same chaos in the future.

Preparedness planning and emergency response require experience and training. This plan should be structured in a document that can be used as a guide in handling crisis. For the Bili-Bili Dam, the planning documents are known as the Emergency Action Plan (RTD) which is updated every five years and the Emergency Action Plan (SOP) Guidelines that follow the RTD update. This RTD has been updated for the second edition in mid-2018 and has been disseminated to government agencies in the regent level in August 2018.

However, some important notes should be addressed to this RTD document. For example, there was no explanation or guidance related to the form of socialization or campaign and crisis messages regarding the potential risks. This document also did not mention any strategies or actions that empower the community to take action when confront the crisis. Moreover, the document did not explain in detail the impacts of damage, the affected areas and the estimated number of the affected populations, as well as the flow of information to the affected communities. Even data inaccuracies were found with comparison to the empirical facts during the crisis. For example, the RTD document has described that the handling procedure in the Alert status has to anticipate the evacuation in zone 1 . In fact, the affected area was zone 2 , while the guide has not paid any attention to handling status in this zone. Re-identification and accuracy need to be rearranged based on the evaluation of the events for integrated disaster management in the future.

In general, disaster management planning of the Bili-Bili Dam refers to the national standards of the Ministry of Public Works and Public Housing. Thus, it is necessary to adopt the local systems for more effective handling, to strengthen local institutions, to increase community empowerment, as well as to adopt an integrated approach at the district level to seriously take disaster management efforts.

As mentioned beforehand, this study found that the emergency information dissemination was slow and not complete. Public has known the emergency situation from many sources, especially through social media. However, what was actually happening and what actions should be taken, were not clear enough. Paltalla et al. (2012) has proposed a number of recommendations to overcome the gaps in crisis communication practices between public authorities, non-government organizations and stakeholders, including the problem of authorities who are obliged to provide information as quickly as possible without ignoring accuracy and responsibility. According to Paltalla et al. (2012), efficient coordination must be based on mutual agreement and adequate capacity, through which the command system can be used to assist coordination so that it is not rigid in following the standard preparedness plan. Besides, adequate knowledge of the roles, tasks and work 
methods between actors is needed so as not to impede the ability to work together. In this cooperation, public authorities need to emphasize their position as the main source of information and protect survivors from media pressure. Also, the authorities should increase cooperative training; build public trust through openness and empathy when explaining alternative decisions and steps; and provide facilities and experts.

Communication is one of the important factors in handling emergency situations. When an emergency occurs, communication must be done immediately because everyone needs the accurate information. Thus, in any emergency planning, an important component of preparedness programs is crisis communication. Moreover, the crisis situation generally involves many parties and participants. Crisis communication provides enough information to make decisions, and the decision is then communicated to participants (Puspito et al., 2015). The implementation of this process has not been carried out maximally by the managers, including the regional government and BPBD. Coordination efforts between agencies and information templates in the form of hazard status reports that have been made by managers have not touched on the aspects of community empowerment.

Awareness of the Bili-Bili Dam management regarding the potential large disasters from the dam has guided them to update information in the RTD document. However, the application of risk communication has not been arranged properly. Much of the risk communication as practiced in the public health combines several features of public messages, usually carried out in the mainstream media, as a general persuasive campaign (Reynolds \& Seeger, 2005). They seek to inform the public and change their behaviour in ways that protect and improve public health and safety. In this case, the dam manager should also seek risk communication actions in the form of social campaigns, such as the use of outdoor communication media to provide information to the public about the dam, the hazard levels in the dam operational processes, the impacts, the risk areas, threatened communities, and how rescue efforts can be carried out independently.

Some basic principles in planning crisis communications, according to Collins et al. (2016), are reducing inappropriate actions by the public; delivering clear and consistent messages across all media; ensuring diverse media channels; being consistent so as not to cause rumours and inaccurate information; empowering the public to make better decisions; and becoming flexible with a variety of situations. Referring to these principles, the management of the Bili-Bili dam has not effectively planned and carried out communications in disaster management. During the early phase of emergency situation, preparedness communication was effective enough without creating panic. However, when the crisis was getting worse, the communication was slow and ineffective. According to the CERC, pre-crisis communication must begin long before the event occurs (Reynolds \& Seeger, 2005). By preparing a crisis communication standard, Shittu, Parker \& Mock (2018) argued that solutions to effective emergency responses do not result from sporadic efforts, but rather require continuous inventory, monitoring and data collection. This should be an important note for managers of the Bili-Bili dam in planning the future crisis communication.

The importance of crisis communication in conveying information quickly during the disasters is one way to support disaster management. According to Bachtiar Chamsah (Santoso, 2011), in implementing disaster management, regional governments must prepare a Disaster Management Contingency Plan, which includes analysis of disaster-prone areas, identification of potential and source systems that can be mobilized, and application of strategic steps in the disaster event. In this context, the community must be positioned as 
the subject, not as an object in the disaster management, so that they know the threats in their area and are able to increase their capacity to deal with the hazards through the community based disaster risk reduction.

Generally, these practical recommendations can be done if the dam manager runs the public relations functions within his organization. The role of PR in crisis communication planning is very important because this process requires communication skills in determining appropriate communication strategies in all forms of information needed, as well as determining who must receive the information in order to achieve organizational goals.

\section{CONCLUSION}

The study found that the emergency responses and communications of the Bili-Bili Dam management follow the increase of the hazard status of the dam, which is based on the increase of water level. The emergency responses are carried out based on the Emergency Action Plan and Standard Operational Procedures documents. Based on these documents, emergency responses and communications would involve some related government bodies. There are four levels of hazard status, namely normal, wary, alert, and caution. The higher status would involve higher government bureaucracy.

This study concluded that at the early stage of the emergency situation, preparedness communication was effective enough without creating panic. But, when the emergency situations occurred, the emergency information disseminations were ineffective. The study also concluded that local people are posited merely as audience of the emergency information and object of the emergency responses, especially to be evacuated. Besides, the emergency responses were not well communicated with the external stakeholders. The community only received the results of the coordination, while there were many public expectations that need to be adjusted and fulfilled. The weakness of the emergency management of the Bili-Bili Dam was at this stage.

In the near future, this study suggests the management of Bili-Bili Dam and another related authority to comprehensively evaluate the emergency responses and communications during the crisis. This research suggests to involve local people to take positive actions during the crisis. In the event of emergency, the need to communicate immediately and accurately is a fundamental requirement that will encourage person or group of people to reduce uncertainty. Thus, the crisis awareness needs to be shared to all stakeholders through developing and implementing appropriate crisis communication planning. It will provide public understanding about what kind of crisis is happening and what are the right actions should be taken. This will be very helpful in overcoming all stages of emergency management. In this context, the role of public relations and communication planning should be highlighted to develop risk management planning as well as to increase public trust in the organization's ability to manage the crisis. 


\section{ACKNOWLEDGEMENT}

The researcher would thank for the support from the Communication Studies Program of Fajar University, Institute of Research and Community Services of Fajar University, and Balai Besar Wilayah Sungai Pompengan Jeneberang Makassar (BBWSPJ).

\section{BIODATA}

Rahmita Saleh is a lecturer at Communication Department, Faculty of Economic and Social Sciences, Fajar University, Indonesia. Email: rahmitasaleh@unifa.ac.id

Yusmanizar is a lecturer at Communication Department, Faculty of Economic and Social Sciences, Fajar University, Indonesia. Email: ninayusmanizar@unifa.ac.id 


\section{REFERENCES}

Aerts, S. (2013). Applying the CERC model within the context of extreme weather: A study about the influence of the timing and efficacy beliefs on information seeking and selfprotective behaviours (Master's thesis, University of Twente). Retrieved from https://essay.utwente.nl/63434/

Biro Komunikasi Publik Kementerian Pekerjaan Umum dan Perumahan Rakyat. (2019). Kementerian PUPR pantau terus tinggi muka air Bendungan Bili-Bili. Retrieved from http://sda.pu.go.id/bbwspompenganjeneberang

Budi, S. (2012). Komunikasi bencana: Aspek sistem (koordinasi, informasi dan kerjasama). Jurnal Aspikom, 1(4), 363-372.

Collins, M., Neville, K., Hynes, W., \& Madden, M. (2016). Communication in a disaster - The development of a crisis communication tool within the S-HELP Project. Journal of Decision Systems, 25(sup1), 160-170. doi: 10.1080/12460125.2016.1187392

Djalante, R., \& Garschagen, M. (2017). A review of disaster trend and disaster risk governance in Indonesia: 1900-2015. In Djalante, R., Garschagen, M., Thomalla, F., \& Shaw, R. (Eds.), Disaster risk reduction in Indonesia (pp. 21-56). Gewerbestrasse, Switzerland: Springer International Publishing AG.

Djalante, R., Garschagen, M., Thomalla, F., \& Shaw, R. (2017). Introduction: Disaster risk reduction in Indonesia: Progress, challenges, and issues. In Djalante, R., Garschagen, M., Thomalla, F., \& Shaw, R. (Eds.), Disaster risk reduction in Indonesia (pp. 1-17). Gewerbestrasse, Switzerland: Springer International Publishing AG.

Fischer, D., Posegga, O., \& Fischbach, K. (2016). Communication barriers in crisis management: A literature review. Twenty-Fourth European Conference on Information Systems (ECIS) (pp. 1-18).

Kementerian Pekerjaan Umum dan Perumahan Rakyat. (2018). Rencana tindak darurat BiliBili. Makassar: Balai Besar Wilayah Sungai Pompengan Jeneberang.

Mardiah, A. N. R., Lovett, J. C., \& Evanty, N. (2017). Toward integrated and inclusive disaster risk reduction in Indonesia: Review of regulatory frameworks and institutional networks. In Djalante, R., Garschagen, M., Thomalla, F., \& Shaw, R. (Eds.), Disaster risk reduction in Indonesia (pp. 57-84). Gewerbestrasse, Switzerland: Springer International Publishing AG.

Mohajan, H. K. (2018). Qualitative research methodology in social sciences and related subjects. Journal of Economic Development, Environment and People, 7(1), 23-48.

Nazaruddin, M. (2017). Media and visual representation of disaster: Analysis of Merapi eruption in 2010. In Djalante, R., Garschagen, M., Thomalla, F., \& Shaw, R. (Eds.), Disaster risk reduction in Indonesia (pp. 307-333). Gewerbestrasse, Switzerland: Springer International Publishing AG.

Nugroho, S. P. (2019, January 25). Banjir landa 53 kecamatan di Sulawesi Selatan, 8 tewas, 4 hilang dan ribuan warga mengungsi. Retrieved from https://www.bnpb.go.id

Paltalla, P., Boano, C., Lund, R., \& Vos, M. (2012). Communication gaps in disaster management: Perceptions by experts from governmental and non-governmental organizations. Journal of Contingencies and Crisis Management, 20(1), 1-12. doi: 10.1111/1468-5973.2011.00656.x

Parker, C.F., Stern, E. K., Paglia, E., \& Brown, C. (2009). Preventable catastrophe? The hurricane Katrina disaster revisited. Journal of Contingencies and Crisis Management, 17(4), 206-220. doi: org/10.1111/j.1468-5973.2009.00588.x 
Puspito, E., Sumardjo, Sumarti, T., \& Muljono, P. (2015). Model komunikasi resiko kesiapan masyarakat menghadapi bencana gunung api (Doctoral dissertation, Institut Pertanian Bogor). Retrieved from https://repository.ipb.ac.id

Pyles, L., Svistova, J., Ahn, S., \& Birkland, T. (2017). Citizens participation in disaster recovery projects and programmes in rural communities: a comparison of the Haiti earthquake and hurricane Katrina. Disasters, 42(3). doi: org/10.1111/disa.12260

Reynolds, B., \& Seeger, M. W. (2005). Crisis and emergency risk communication as an integrative model. Journal of Health Communication, 10, 43-55. doi: $10.1080 / 10810730590904571$

Rusdianto, E. (2019, February 7). Banjir Sulawesi Selatan cermin buruk pencegahan bencana. Mongabay. Retrieved from https://www.mongabay.co.id

Santoso, E. H. (2011). Eksistensi komunikasi dalam menghadapi bencana. Retrieved from http://repository.untar.ac.id/474/1/1243-2940-1-PB.pdf

Satker Operasi \& Pemeliharaan SDA Pompengan-Jeneberang. (2018). Laporan panduan rencana tindak darurat (SOP) pemutakhiran RTD bendungan. Makassar: Multimera Harapan.

Shittu, E., Parker, G., \& Mock, N. (2018). Improving communication resilience for effective disaster relief operations. Environment Systems and Decisions, 38(3), 379-397. doi: 10.1 037/0003-066X.48.1.49

SISDA BBWSPJ. (2019). Kronologis kenaikan tinggi muka air bendungan Bili-Bili. Retrieved from http://sda.pu.go.id/bbwspompenganjeneberang

Spence, P. R., Lachlan, K. A., \& Griffin, D. R. (2007). Crisis communication, race, and natural disasters. Journal of Black Studies, 37(4), 539-554. doi: 10.1177/0021934706296192

Taufiqqurahman, M. (2019, January 30). 78 meninggal, banjir Sulsel paling parah dalam 6 tahun terakhir. DetikNews. Retrieved from https://news.detik.com

Tribun Timur. (2019, February 5). Makassar nyaris tenggelam seperti 1976.

West, R., \& Turner, L. H. (2008). Pengantar teori komunikasi: Analisis dan aplikasi. Jakarta: Salemba Humanika. 